\title{
The importance of the form of nitrogen on microbial protein synthesis in the rumen of cattle receiving grass silage and continuous intrarumen infusions of sucrose
}

\author{
BY J. A. ROOKE AND D. G. ARMSTRONG \\ Department of Agricultural Biochemistry and Nutrition, University of Newcastle upon \\ Tyne, Newcastle upon Tyne NE1 7RU
}

(Received 18 February 1988 - Accepted 3 August 1988)

1. In a $4 \times 4$ Latin square design experiment, four cattle were given grass silage in two meals per d to satisfy maintenance energy requirements. In addition, sucrose $(170 \mathrm{~g} / \mathrm{kg}$ silage dry matter (DM)) was infused intraruminally at a constant rate with no nitrogen supplementation; with the infusion intraruminally of either casein $(23 \mathrm{~g} / \mathrm{kg}$ silage DM) or urea $(8 \mathrm{~g} / \mathrm{kg}$ silage DM); or with soya-bean meal $(64 \mathrm{~g} / \mathrm{kg}$ silage DM) fed in two equal portions.

2. Samples of duodenal digesta representative of a $24 \mathrm{~h}$ period were obtained using chromium-EDTA and ytterbium acetate for flow estimation and ${ }^{35} \mathrm{~S}$ as a marker of microbial $\mathrm{N}$ entering the small intestine. Samples of rumen fluid were also taken for estimation of rumen $\mathrm{pH}$ and concentrations of ammonia- $\mathrm{N}$ and volatile fatty acids. Estimates of apparent organic matter (OM) and $\mathrm{N}$ digestibility and of the rates of silage DM and $\mathrm{N}$ disappearance from porous synthetic-fibre bags incubated in the rumen were also made.

3. The $\mathrm{N}$ supplements had no significant effects on rumen $\mathrm{pH}$, concentrations of volatile fatty acids, their molar proportions or the disappearance of $\mathrm{DM}$ or $\mathrm{N}$ from porous synthetic-fibre bags. $\mathrm{N}$ supplementation increased rumen ammonia- $\mathrm{N}$ concentrations (urea, $P<0-05$; casein, soya-bean meal, not significant).

4. $N$ supplementation had no significant effects on the digestion of $O M$, acid-detergent fibre or soluble carbohydrate.

5. Infusion of casein increased the quantities of total non-ammonia- $\mathrm{N}$ (not significant) and microbial $\mathrm{N}$ $(P<0.05)$ entering the small intestine daily and the efficiency of rumen microbial $\mathrm{N}$ synthesis (not significant). Giving soya-bean meal twice daily resulted in marginal increases in the quantities of non-ammonia- $N$ and microbial $\mathrm{N}$ entering the small intestine, while infusing urea intraruminally had no effect.

The efficiency of rumen microbial nitrogen synthesis in animals given diets of grass silage (e.g. Thomas et al. 1980; Thomson et al. 1981) is often lower than the mean value of $32 \mathrm{~g} \mathrm{~N} / \mathrm{kg}$ organic matter $(\mathrm{OM})$ apparently digested in the rumen reported for all diets (Agricultural Research Council, 1984). Continuous intrarumen infusion of soluble carbohydrates (CHO), such as sucrose, has been shown to stimulate rumen microbial $\mathrm{N}$ synthesis in cattle (Rooke et al. 1987) and sheep (Huhtanen \& Ala-Seppala, 1987) fed on silage. Infusion of casein with soluble CHO (Rooke et al. 1987) resulted in an even more marked stimulation of the amounts of microbial $\mathrm{N}$ synthesized in the rumen of cattle.

Since Rooke et al. (1987) only infused a protein-N source (casein) with soluble CHO, it was decided to investigate whether the form of the $\mathrm{N}$ supplement (non-protein or protein$\mathrm{N}$ )_was an important factor in the observed stimulation of rumen microbial $\mathrm{N}$ synthesis. This was achieved by the infusion of casein or urea intraruminally with sucrose and compared with giving soya-bean meal to ascertain whether feeding a rumen-degradable protein supplement twice daily would produce a similar stimulation of microbial $\mathbf{N}$ synthesis to that expected when $\mathrm{N}$ was continuously infused.

A preliminary report of some of this work has been published (Rooke \& Armstrong, $1987 a$ ).

\section{EXPERIMENTAL}

Animals

Two Jersey cattle (approximate live weights, 400 and $475 \mathrm{~kg}$ ) and two Friesian cattle (approximate live weights, 525 and $630 \mathrm{~kg}$ ) were used in the experiment. All were adult 
females and non-pregnant and non-lactating. Each was equipped with a rumen cannula and either a simple (Friesians) or re-entrant (Jerseys) cannula in the proximal duodenum.

\section{Diets and experimental procedure}

The cattle were fed on grass silage and sucrose was infused into the rumen at a continuous rate throughout the experiment. The animals were given, according to a $4 \times 4$ Latin square experimental design, either no $\mathrm{N}$ supplement or supplements of either urea or casein infused intraruminally, or a supplement of soya-bean meal which was fed.

The grass silage was prepared from a second cut of a mixture of perennial (Lolium perenne) and hybrid ryegrasses (L. perenne $\times$ L. multiflorum) (first cut, 28 May 1985), harvested with a precision-chop forage harvester on 17 July 1985. The grass was wilted for $24 \mathrm{~h}$ and ensiled in a $100 \mathrm{t}$ bunker silo with the application of an additive (Pioneer 1177; Pioneer Overseas Corp., Johnston, Iowa, USA) such that $2 \times 10^{4}$ lactic acid bacteria were applied/g grass ensiled.

Feed was offered to each animal twice daily in equal amounts at 08.00 and 16.00 hours throughout the experiment. The amounts of silage offered supplied sufficient metabolizable energy, estimated from its modified acid-detergent-fibre content (Givens, 1986) to provide the maintenance energy requirements of each animal (Ministry of Agriculture, Fisheries and Food, 1975). Water and mineralized salt licks were freely available.

Each experimental period was of $21 \mathrm{~d}$ duration and consisted of a $14 \mathrm{~d}$ infusion period followed by a $7 \mathrm{~d}$ rest period. During each experimental period a solution of sucrose was infused intraruminally at a rate of $125 \mathrm{ml} / \mathrm{h}$. The quantities of sucrose infused daily were such that $170 \mathrm{~g}$ sucrose were infused $/ \mathrm{kg}$ silage dry matter (DM) offered to each animal. The composition of the soya-bean meal fed and the amounts of casein and urea infused intraruminally and soya-bean meal fed daily are given in Table 1 . Throughout the infusion period chromium-EDTA ( $120 \mathrm{mg} \mathrm{Cr} / \mathrm{kg}$ silage DM intake) was included in the nutrient infusion and ytterbium acetate ( $100 \mathrm{mg} \mathrm{Yb} / \mathrm{kg}$ silage $\mathrm{DM}$ intake) was infused separately; finally $2.5 \mathrm{mCi}^{35} \mathrm{SO}_{4}$ were added to the nutrient infusion on day 9 of each experimental period.

\section{Sampling procedures}

Representative samples of the silage, soya-bean meal and infusates were obtained from each period. Spot samples of duodenal digesta $(500 \mathrm{~g})$, rumen fluid $(50 \mathrm{ml})$ and of faeces (by 'grab' sampling or as freshly voided faeces) were obtained from days 12 to 14 of each period using a sampling schedule (Faichney, 1980) to give twelve samples at 2 -h intervals representative of a $24 \mathrm{~h}$ feeding period. From each sample $250 \mathrm{~g}$ digesta were composited to give a representative $24 \mathrm{~h}$ digesta sample. From this composite sample a duodenal microbial fraction was prepared by differential centrifugation according to Rooke et al. (1985); briefly duodenal digesta were filtered through muslin to remove fibre, centrifuged at $500 \mathrm{~g}$ for $5 \mathrm{~min}$ to remove feed particles and the duodenal microbial fraction recovered from the supernatant fraction by centrifugation at $10000 \mathrm{~g}$ for $30 \mathrm{~min}$. A centrifuged duodenal digesta sample was also prepared by centrifuging whole digesta at $10000 \mathrm{~g}$ for $15 \mathrm{~min}$. Faecal samples were dried at $65^{\circ}$ and then composited on a DM basis to give one sample/animal per period. Finally, four porous synthetic-fibre (psf) bags $(45 \mu \mathrm{m}$, $150 \times 60 \mathrm{~mm}$ ) containing fresh silage equivalent to $5 \mathrm{~g}$ silage DM were inserted into the rumen of each animal at 11.00 hours on day 12, and removed at intervals of $6,12,26$ and $52 \mathrm{~h}$ thereafter. On removal from the rumen the psf bags were thoroughly washed in cold water and then dried at $65^{\circ}$ in a forced-draught oven. 
Table 1. The chemical composition ( $\mathrm{g} / \mathrm{kg}$ dry matter) of the silage and soya-bean meal. The quantities of casein and urea infused daily intraruminally and of soya-bean meal fed twice daily $(\mathrm{g} / \mathrm{d})$ are also given

\begin{tabular}{|c|c|c|c|c|}
\hline & Silage* & $\begin{array}{c}\text { Soya-bean } \\
\text { meal }\end{array}$ & Casein & Urea \\
\hline Dry matter $(\mathrm{g} / \mathrm{kg})$ & 232 & 865 & & \\
\hline Organic matter & 917 & 924 & & \\
\hline Acid-detergent fibre & 308 & & & \\
\hline Water-soluble carbohydrate & 15 & & & \\
\hline Total nitrogen & $20 \cdot 2$ & 75.8 & & \\
\hline Ammonia-N (g/kg N) & 89 & & & \\
\hline Acetic acid & 17 & & & \\
\hline Butyric acid & 1 & & & \\
\hline Lactic acid & 92 & & & \\
\hline Ethanol & 6 & & & \\
\hline $\mathrm{pH}$ & 3.9 & & & \\
\hline Daily intake ( $\mathrm{g} / \mathrm{kg}$ silage $\mathrm{DM})$ & - & 64 & 23 & 8 \\
\hline
\end{tabular}

* Dry matter determined by toluene distillation.

\section{Analytical procedures}

Total and centrifuged duodenal digesta samples and duodenal microbial fractions were freeze-dried. All samples were milled before analysis by the methods described by Rooke et al. (1987). Briefly, OM was determined by ashing dried samples at $550^{\circ}, \mathrm{N}$ by the Kjeldahl procedure, soluble $\mathrm{CHO}$ as the sum of free glucose plus $\alpha$-linked glucose polymers (MacRae \& Armstrong, 1969) and acid-detergent fibre according to Van Soest \& Wine (1967). The ${ }^{35} \mathrm{~S}$ : non-ammonia-N (NAN) contents of the total duodenal, centrifuged duodenal and duodenal microbial fractions were analysed according to Mathers \& Miller (1980). The Cr contents of infusates and digesta samples were determined as described by Rooke et al. (1985) and the $\mathrm{Yb}$ contents of infusates and digesta samples according to Siddons et al. (1985b) except that Yb concentrations were measured by the known-addition method. Rumen volatile fatty acids were determined by gas-liquid chromatography (Cottyn \& Boucque, 1968) and silage analyses were performed as described by Rooke et al. (1988).

\section{Calculation of results}

Faecal excretion was estimated using $\mathrm{Yb}$ as a non-absorbable marker (Siddons et al. 1985 $\mathrm{b}$; Peyraud, 1987). Nutrient flows to the small intestine were estimated according to the dualphase-marker method of Faichney (1986) from the concentrations of $\mathrm{Cr}$ and $\mathrm{Yb}$ in duodenal digesta DM and centrifuged duodenal digesta DM for animals with both types of duodenal cannula. An effective infusion rate for $\mathrm{Cr}$ was calculated from the faecal ratio $\mathrm{Cr}: \mathrm{Yb}$ (Faichney, 1986) since the ratio $\mathrm{Cr}: \mathrm{Yb}$ (J. A. Rooke and C. Rymer, unpublished results and values from this experiment) in faecal DM was significantly $(P<0.01)$ less (0.89-fold) than the ratio $\mathrm{Cr}: \mathrm{Yb}$ infused daily, suggesting a net loss of $\mathrm{Cr}$ from the gastrointestinal tract. Additionally the $\mathrm{Cr}: \mathrm{Yb}$ ratio in duodenal digesta $\mathrm{DM}$ obtained from cattle with re-entrant cannulas was also significantly $(P<0.01)$ less than the infused $\mathrm{Cr}$ : $\mathrm{Yb}$ ratio but not significantly different from the faecal $\mathrm{Cr}$ : $\mathrm{Yb}$ ratio. Thus all $\mathrm{Cr}$ absorption was assumed to have taken place before the proximal duodenum, possibly as a result of changes of rumen osmolality (Dobson et al. 1976) associated with feeding silage twice daily. The 
Table 2. Mean values for $p H$ and for the concentrations of ammonia-nitrogen $(m g / l)$ and volatile fatty acids (mmol/l) in the rumen fluid of cattle given diets of grass silage and intrarumen infusions of sucrose unsupplemented or supplemented with three $N$ supplements $\dagger$. The molar proportions of individual fatty acids ( $\mathrm{mmol}$ acid/mol total volatile fatty acids) are also given

\begin{tabular}{lccccc}
\hline N supplement... & None & Casein & Urea & Soya bean & SE $\ddagger$ \\
\hline pH & $6 \cdot 75$ & $6 \cdot 72$ & $6 \cdot 71$ & $6 \cdot 71$ & $0 \cdot 039$ \\
Ammonia-N & 49 & 61 & $72^{*}$ & 58 & $4 \cdot 5$ \\
Volatile fatty acids & 96 & 93 & 100 & 99 & $3 \cdot 6$ \\
$\quad$ Total & 657 & 656 & 653 & 644 & $18 \cdot 7$ \\
Acetic & 197 & 203 & 194 & 199 & $3 \cdot 4$ \\
Propionic & 5 & 4 & 7 & 7 & $0 \cdot 7$ \\
Isobutyric & 112 & 108 & 113 & 118 & $15 \cdot 0$ \\
$n$-Butyric & 12 & 14 & 14 & 14 & 1.9 \\
isovaleric & 20 & 19 & 20 & 19 & $3 \cdot 3$ \\
$n$-Valeric & & & & & \\
\hline
\end{tabular}

* Mean value was significantly different from that for diet with no $\mathrm{N}$ supplement $P<0.05$.

$\uparrow$ For details, see p. 114.

$\$$ SE of mean with $5 \mathrm{~d}$ for four observations; for casein three observations only.

Table 3. The disappearance of silage dry matter and nitrogen from porous synthetic-fibre bags incubated in the rumen of the cattle

(Mean values with their standard errors are given for constants $a^{\prime}, b$ and $c$ relating to the equation $p=$ $a^{\prime}-b \mathrm{e}^{-c t}$ for each of the four diets where $p$ is the proportion of dry matter or $\mathrm{N}$ which had disappeared from bags after time $t(\mathrm{~h})$ )

\begin{tabular}{|c|c|c|c|c|c|c|c|c|}
\hline \multirow[t]{2}{*}{ Constant ... } & \multicolumn{2}{|c|}{$a^{\prime}$} & \multicolumn{2}{|c|}{$b$} & \multicolumn{2}{|c|}{$c$} & \multirow[b]{2}{*}{$r^{2}$} & \multirow[b]{2}{*}{$\mathrm{df}$} \\
\hline & Mean & SE & Mean & $\mathrm{SE}$ & Mean & $\mathrm{SE}$ & & \\
\hline \multicolumn{9}{|l|}{ Dry matter } \\
\hline \multicolumn{9}{|l|}{$\mathrm{N}$ supplement $\dagger$} \\
\hline None & 0.88 & 0.073 & 0.52 & 0.067 & 0.035 & 0.0106 & 0.91 & 17 \\
\hline Casein & 1.00 & $0 \cdot 180$ & 0.64 & $0 \cdot 167$ & 0.024 & 0.0117 & 0.90 & 12 \\
\hline Urea & 0.98 & 0.088 & 0.55 & $0 \cdot 081$ & $0 \cdot 033$ & 0.0110 & 0.95 & 17 \\
\hline Soya-bean & $0 \cdot 86$ & $0 \cdot 076$ & $0 \cdot 51$ & $0 \cdot 070$ & 0.039 & 0.0131 & 0.93 & 17 \\
\hline \multicolumn{9}{|l|}{ Nitrogen } \\
\hline \multicolumn{9}{|c|}{$\mathrm{N}$ supplement ${ }^{\dagger}$} \\
\hline None & 0.94 & 0.017 & $0 \cdot 27$ & 0.021 & 0.082 & 0.0162 & 0.92 & 17 \\
\hline Casein & 0.94 & 0.023 & $0 \cdot 26$ & 0.027 & 0.069 & 0.0178 & 0.92 & 12 \\
\hline Urea & 0.93 & $0 \cdot 012$ & 0.25 & 0.015 & 0.088 & 0.0128 & $0-91$ & 17 \\
\hline Soya-bean & 0.93 & $0 \cdot 013$ & $0 \cdot 26$ & 0.017 & 0.096 & 0.0160 & $0-89$ & 17 \\
\hline
\end{tabular}

No significant differences between diets.

$\dagger$ For details, see p. 114.

proportion of microbial NAN in duodenal NAN was calculated according to Mathers \& Miller (1980). The proportionate disappearances of DM and $\mathrm{N}$ from psf bags in the rumen were fitted using a Maximum Likelihood Program (Ross, 1980) to an exponential function of the form

$$
p=a^{\prime}-b \mathrm{e}^{-c t}
$$


Table 4. The mean quantities $(\mathrm{kg} / 24 \mathrm{~h})$ of organic matter $(O M)$, soluble carbohydrate $(C H O)$ and acid-detergent fibre $(A D F)$ consumed and entering the small intestine of cattle infused intraruminally. The quantities of $O M$ excreted in the faeces $(\mathrm{kg} / 24 \mathrm{~h})$, the apparent digestibility of $O M$ and the proportion of digestible $O M$ digested in the rumen (DOMDR) are also given

\begin{tabular}{|c|c|c|c|c|c|}
\hline Nitrogen supplement* ... & None & Casein & Urea & Soya bean & $\mathrm{SE}^{\dagger}$ \\
\hline \multicolumn{6}{|c|}{ OM } \\
\hline $\begin{array}{l}\text { Intake from: } \\
\text { Silage } \\
\text { Soya-bean meal } \\
\text { Infusion } \\
\text { Total }\end{array}$ & $\begin{array}{l}5 \cdot 23 \\
-\overline{0 \cdot 80} \\
6 \cdot 03\end{array}$ & $\begin{array}{c}5 \cdot 46 \\
- \\
0 \cdot 86 \\
6 \cdot 32\end{array}$ & $\begin{array}{l}5 \cdot 26 \\
- \\
0.97 \\
6 \cdot 23\end{array}$ & $\begin{array}{l}5 \cdot 25 \\
0 \cdot 30 \\
0 \cdot 84 \\
6 \cdot 39\end{array}$ & $\begin{array}{l}- \\
- \\
-\end{array}$ \\
\hline $\begin{array}{l}\text { Entering small intestine } \\
\text { In faeces } \\
\text { Apparent digestibility } \\
\text { DOMDR }\end{array}$ & $\begin{array}{l}2 \cdot 37 \\
1 \cdot 33 \\
0 \cdot 78 \\
0 \cdot 78\end{array}$ & $\begin{array}{l}2 \cdot 63 \\
1 \cdot 46 \\
0 \cdot 77 \\
0 \cdot 77\end{array}$ & $\begin{array}{l}2.59 \\
1.54 \\
0.76 \\
0.78\end{array}$ & $\begin{array}{l}2.54 \\
1 \cdot 36 \\
0.76 \\
0.76\end{array}$ & $\begin{array}{l}0.096 \\
0 \cdot 065 \\
0.011 \\
0.016\end{array}$ \\
\hline \multicolumn{6}{|c|}{ Soluble $\mathrm{CHO}$} \\
\hline $\begin{array}{l}\text { Intake from: } \\
\text { Silage } \\
\text { Infusion } \\
\text { Total }\end{array}$ & $\begin{array}{l}0.09 \\
0.80 \\
0.89\end{array}$ & $\begin{array}{l}0 \cdot 09 \\
0 \cdot 70 \\
0 \cdot 79\end{array}$ & $\begin{array}{l}0.08 \\
0.92 \\
1.00\end{array}$ & $\begin{array}{l}0.08 \\
0.84 \\
0.92\end{array}$ & - \\
\hline Entering small intestine & 0.03 & 0.03 & 0.02 & 0.03 & 0.002 \\
\hline \multicolumn{6}{|c|}{$\mathrm{ADF}$} \\
\hline $\begin{array}{l}\text { Intake from: } \\
\text { Silage } \\
\text { Soya-bean meal } \\
\text { Total }\end{array}$ & $\frac{1 \cdot 70}{1 \cdot 70}$ & $\frac{1 \cdot 87}{1 \cdot 87}$ & $\frac{1 \cdot 70}{1 \cdot 70}$ & $\begin{array}{l}1.68 \\
0.05 \\
1 \cdot 73\end{array}$ & - \\
\hline Entering small intestine & 0.49 & $0 \cdot 52$ & 0.51 & 0.53 & 0.029 \\
\hline
\end{tabular}

No significant differences between diets.

* For details, see p. 114.

$\dagger \mathrm{SE}$ of mean with $5 \mathrm{df}$ for four observations; for casein three observations only.

where $p$ is the proportion of DM or $\mathrm{N}$ disappearing after time $t(\mathrm{~h})$ and $a^{\prime}, b$ and $c$ are constants.

\section{Statistical analysis}

Results were analysed by analysis of variance for Latin square design experiments using a least squares solution as one animal was removed from one period for reasons not connected with the experimental diets fed. Differences between each $\mathrm{N}$ supplemented diet and the diet containing no $\mathrm{N}$ supplement were determined according to Dunnett (1955). Differences between fitted curves for the psf-bag values were analysed by parallel curve analysis (Ross, 1980).

\section{RESULTS}

The silage given in the experiment was of moderate $\mathbf{N}$ content (Table 1) and was wellfermented, having a low $\mathrm{pH}$, high concentration of lactic acid and low concentrations of acetic and butyric acids.

The addition of different $\mathbf{N}$ sources to diets of grass silage supplemented with intrarumen infusions of sucrose increased rumen ammonia-N concentrations (Table 2); however, these 
Table 5. The mean quantities of total nitrogen consumed by the cattle $(\mathrm{g} / 24 \mathrm{~h})$, infused intraruminally and the quantities of non-ammonia- $N(N A N)$, microbial $N$ and feed $N A N$ entering the small intestine, the apparent efficiency of microbial $N$ synthesis $(g N / k g$ organic matter apparently digested in the rumen) and the apparent degradability of feed $N$ in the rumen

\begin{tabular}{|c|c|c|c|c|c|}
\hline $\mathrm{N}$ supplement $\dagger \ldots$ & None & Casein & Urea & Soya bean & $\mathrm{SE} \ddagger$ \\
\hline $\begin{array}{l}\mathrm{N} \text { intake from } \\
\text { Silage }\end{array}$ & 114 & 120 & 116 & 117 & - \\
\hline Soya-bean meal & - & - & - & 23 & - \\
\hline Infusion & - & 22 & 24 & - & - \\
\hline Total & 114 & 142 & 140 & 140 & - \\
\hline \multicolumn{6}{|l|}{$\mathrm{N}$ entering small intestine } \\
\hline Total NAN & 120 & 142 & 128 & 127 & $5 \cdot 4$ \\
\hline Microbial N & 105 & $126^{*}$ & 108 & 112 & $3 \cdot 4$ \\
\hline Feed NAN§ & 15 & 16 & 20 & 15 & $3 \cdot 2$ \\
\hline $\begin{array}{l}\text { Efficiency of microbial } \mathrm{N} \\
\text { synthesis }\end{array}$ & - & 34 & 29 & 30 & 1.7 \\
\hline Apparent feed $N$ degradability $\S$ & $0 \cdot 88$ & 0.89 & 0.87 & 0.90 & 0.020 \\
\hline
\end{tabular}

* Mean value was significantly different from that for the diet with no $\mathrm{N}$ supplement $(P<0.05)$.

$\dagger$ For details, see p. 114.

$\$$ SE of mean with $5 \mathrm{df}$ for four observations; for casein, three observations only.

$\S$ Includes endogenous $\mathrm{N}$ secretions. Values for degradability of feed $\mathrm{N}$ calculated from the difference between $\mathrm{N}$ intake and duodenal (NAN-microbial $\mathrm{N}$ ).

increases in ammonia- $\mathrm{N}$ concentrations were significant $(P<0.05)$ only when urea was the $\mathrm{N}$ source. No $\mathrm{N}$ supplement had any significant effect on rumen $\mathrm{pH}$, volatile fatty acid concentrations or molar proportions (Table 2). Similarly, neither the rate $(c)$ nor extent (total, $a^{\prime}$; not instantly solubilized, $b$ ) of silage DM or $\mathrm{N}$ disappearance from psf bags (Table 3) incubated in the rumen was affected by $\mathrm{N}$ supplementation.

Neither the quantities of $\mathrm{OM}$, soluble $\mathrm{CHO}$ or acid-detergent fibre entering the small intestine nor the faecal excretion of OM (Table 4) were changed by $\mathrm{N}$ supplementation.

Table 5 shows that only the infusion of casein increased the quantities of NAN entering the small intestine daily, but this increase was not significant $(P>0.05)$. Supplying $N$ in the form of urea or soya-bean meal had small and non-significant effects on NAN flow to the small intestine. From Table 5 it can be seen that the increase in the quantities of NAN entering the small intestine when casein was infused arose from a significant $(P<0.05)$ increase in the quantities of microbial $\mathrm{N}$ synthesized in the rumen. Neither urea nor soyabean meal had any effect on microbial $\mathrm{N}$ flow to the small intestine. The efficiency of rumen microbial $\mathrm{N}$ synthesis was not significantly increased by $\mathrm{N}$ supplementation although higher values were observed when casein was infused. Neither the quantities of undegraded feed NAN entering the small intestine nor apparent feed $\mathrm{N}$ degradability (Table 5) were influenced by the diets fed.

\section{DISCUSSION}

\section{Infusion of casein or urea intraruminally}

A major aim of the present experiment was to establish whether the increases in rumen microbial $\mathrm{N}$ synthesis observed previously (Rooke et al. 1987) when casein was added to a continuous intrarumen infusion of glucose syrup were related to the form of the $N$ 
supplied. Clearly infusion of protein- $\mathrm{N}$ was an important factor, as in the present experiment casein, but not urea, increased the quantities of microbial $\mathbf{N}$ synthesized within the rumen when co-infused with sucrose. Rumen bacterial protein synthesis has been shown to be stimulated by the supply of peptide and amino acid- $\mathrm{N}$ in the presence of simple N sources both in vitro (Maeng et al. 1976; Cotta \& Russell, 1982) and in vivo (e.g., Hume, 1970; McAllan \& Smith, 1984).

Energetically the advantage to rumen bacteria of using preformed amino acids and peptides may arise from the reduced costs of amino acid and peptide transport rather than from reduced biosynthetic costs (Demeyer \& Van Nevel, 1986). In maize-silage-fed cattle Cottrill et al. (1982) observed increases in microbial $\mathrm{N}$ synthesis when fish meal replaced urea in the diet. In grass-silage-fed animals, urea did not influence the quantities of microbial $N$ synthesized in the rumen of sheep (Siddons et al. 1979) whereas in cattle, protein- $\mathrm{N}$ in the form of soya-bean meal has been shown to stimulate microbial $\mathrm{N}$ synthesis (Rooke et al. 1986). Since silage contains large quantities of non-protein- $\mathrm{N}$ in the form of ammonia and amino acid-N, and Chen et al. (1987) have shown that rumen bacteria have a preference for peptide- $N$, then it is possible that in the present experiment casein- $N$ supplied peptide- $\mathrm{N}$ rather than amino acid- $\mathrm{N}$.

\section{Infusion of casein and feeding soya-bean meal}

When soya-bean meal was fed twice daily in the present experiment there was only a marginal increase in the quantities of microbial $\mathrm{N}$ synthesized in the rumen in contrast to the response obtained when casein was infused. Apart from the fact that different protein sources will supply different quantities of each amino acid to the rumen microflora, the most likely explanation for the limited response obtained with soya-bean meal is that the rates of release of $\mathrm{N}$ into the rumen from the soya-bean meal and of energy from sucrose were less well synchronized than when casein was infused. Infusing casein supplied approximately $1 \mathrm{~g}$ casein- $\mathrm{N} / \mathrm{h}$ to the rumen microflora. Using the values of Rooke $e t$ al. (1985) and eqn (2) of Ørskov \& McDonald (1979), it can be calculated that only in the hour immediately after each of the daily feeds would soya-bean meal have supplied more than $1 \mathrm{~g} \mathrm{~N}$. In contrast, for $14 \mathrm{~h}$ of $24 \mathrm{~h}$, soya-bean meal would have supplied less than $0.5 \mathrm{~g} \mathrm{~N} / \mathrm{h}$. Further evidence for the importance of synchronizing the supply of supplementary energy and protein- $\mathrm{N}$ in silage-based diets can be seen from the findings of Newbold et al. (1987). These authors gave a protein supplement consisting predominantly of soya-bean meal to sheep receiving diets of silage and molasses, the whole diet being fed in twenty-four hourly meals/d and thus supplies of energy and protein were synchronized; significant increases in the quantities of microbial $\mathrm{N}$ synthesized in the rumen were observed when the protein supplement was fed. Similarly when protein supplements were fed twice daily, accompanied by cereals, stimulation of the quantities of microbial $\mathrm{N}$ synthesized have been often (Cottrill et al. 1982; Rooke et al. 1986) but not always (Siddons et al. 1979; Rooke \& Armstrong, 1987 b) observed. The need for synchronization of the supplies of protein and energy is probably more acute when silage is fed because of the relatively high rumen $\mathrm{pH}$ (e.g. $6.7-6.8$ in the present experiment) observed with silage which thus encourages extensive absorption of ammonia- $\mathrm{N}$ from the rumen as ammonia is largely in the unionized form (Siddons et al. 1985a).

Although the present experiment confirmed the stimulation of microbial $\mathrm{N}$ synthesis by casein which had been previously observed (Rooke et al. 1987) the extent of the stimulation was much less marked $(0.7$ (present experiment) v. 1.9 (Rooke et al. 1987) g microbial N/g casein-N infused). Since the silage:infused $\mathrm{CHO}$ ratio was similar in the two experiments (6.4:1 present experiment; 7.3:1 Rooke et al. (1987)) and responses to the infusion of sucrose have been obtained in other studies (Gill \& Ulyatt, 1977; Huhtanen \& Ala-Seppala, 
1987), the differing silages fed in each experiment were probably responsible for the between-experiment differences. The silage used by Rooke et al. (1987) had lower $\mathrm{N}$ and higher acid-detergent fibre contents than that used in the present experiment, and was associated with a lower mean rumen ammonia- $\mathrm{N}$ concentration $(28 \mathrm{mg} \mathrm{N} / \mathrm{l})$ than in the current experiment ( $49 \mathrm{mg} \mathrm{N} / \mathrm{l})$. It is possible that the marked stimulation of microbial $\mathrm{N}$ synthesis observed by Rooke et al. (1987) when casein was infused was caused by two factors; first, by meeting an absolute requirement for $\mathrm{N}$ by the rumen biomass and second, by meeting a requirement for protein-N. Since urea gave no response in the present experiment, there was possibly only a requirement for protein- $\mathrm{N}$ to be met with the higher$\mathrm{N}$-containing silage.

The results for the present experiment have confirmed the importance for rumen microbial $\mathrm{N}$ synthesis of including a supply of rumen degradable-protein- $\mathrm{N}$ in silage-based diets, although the extent of stimulation achieved is clearly dependent both on silage composition and the synchronization of supply of protein and energy.

The authors are grateful to the Agricultural and Food Research Council for financial support and to Brian Brown, David Smith and Heather Tingey for the care of the cattle and to Ann Purvis for technical assistance.

\section{REFERENCES}

Agricultural Research Council (1984). The Nutrient Requirements of Ruminant Livestock Suppl. no. 1 Slough: Commonwealth Agricultural Bureaux.

Chen, G., Strobel, H. J., Russell, J. B. \& Sniffen, C. J. (1987). Effect of hydrophobicity on utilization of peptides by ruminal bacteria in vitro. Applied and Environmental Microbiology 53, 2021-2025.

Cotta, M. A. \& Russell, J. B. (1982). Effect of peptides and amino acids on efficiency of rumen bacterial protein synthesis in continuous culture. Journal of Dairy Science 65, 226-234.

Cottrill, B. R., Beever, D. E., Austin, A. R. \& Osborne, D. F. (1982). The effect of protein- and non-proteinnitrogen supplements to maize silage on total amino acid supply in young cattle. British Journal of Nutrition $\mathbf{4 8}$, $527-541$

Cottyn, B. Q. \& Boucque, C. V. (1968). Rapid method for the gas-chromatographic determination of volatile fatty acids in rumen fluid. Journal of Agricultural and Food Chemistry 16, $10 \tau-107$.

Demeyer, D. \& Van Nevel, C. (1986). Influence of substrate and microbial interaction on efficiency of rumen microbial growth. Reproduction, Nutrition, Développement 26, 161-179.

Dobson, A., Sellers, A. F. \& Gatewood, V. H. (1976). Dependence of Cr-EDTA absorption from the rumen on Juminal osmotic pressure. American Journal of Physiology 231, 1595-1600.

Dunnett, C. W. (1955). A multiple comparison procedure for comparing several treatments with a control. Journal of the American Statistical Association 50, 1096-1121.

Faichney, G. J. (1980). The use of markers to measure digesta flow from the stomach of sheep fed once daily. Journal of Agricultural Science, Cambridge 94, 313-318.

Faichney, G. J. (1986). The kinetics of particulate matter in the rumen. In Control of Digestion and Metabolism in Ruminants, pp. 173-195 [L. P. Milligan, W. L. Grovum and A. Dobson, editors]. New Jersey: Prentice Hall.

Gill, M. \& Ulyatt, M. J. (1977). The effect of supplementation with protein, energy and L-methionine, on the digestion of silage by sheep. Journal of Agricultural Research, Cambridge 89, 43-51.

Givens, D. I. (1986). New methods for predicting the nutritive value of silage. In Developments in Silage 1986, pp. 66-75, [B. Stark and M. Wilkinson, editors]. Marlow: Chalcombe Publications.

Huhtanen, P. \& Ala-Seppala, H. (1987). The effect of sugar infusions on nitrogen and fibre digestion in the rumen of cattle given silage based diets. Proceedings of the 8th Silage Conference, Hurley, 1987. pp. 175-176. Hurley: Institute for Grassland and Animal Production.

Hume, I. D. (1970). Synthesis of microbial protein in the rumen. 3. The effect of dietary protein. Australian Journal of Agricultural Research 21, 305-314.

McAllan, A. B. \& Smith, R. H. (1984). The efficiency of microbial protein synthesis in the rumen and the degradability of feed nitrogen between the mouth and abomasum in steers given different diets. British Journal of Nutrition 51, 77-83.

MacRae, J. C. \& Armstrong, D. G. (1969). Studies on intestinal digestion in the sheep. 1. The use of chromic oxide as an indigestible marker. British Journal of Nutrition 23, 15-23. 
Maeng, W. J., Van Nevel, C. J., Baldwin, R. L. \& Morris, J. G. (1976). Rumen microbial growth rates and yields: effects of amino acids and protein. Journal of Dairy Science 59, 68-79.

Mathers, J. C. \& Miller, E. L. (1980). A simple procedure using ${ }^{35} \mathrm{~S}$ incorporation for the measurement of microbial and undegraded food protein in ruminant digesta. British Journal of Nutrition 43, 503-514.

Ministry of Agriculture, Fisheries and Food (1975). Energy Allowances and Feeding Systems for Ruminants. Technical Bulletin no. 33. London: H. M. Stationery Office.

Newbold, C. J., Chamberlain, D. G. \& Thomas, P. C. (1987). The use of sodium bicarbonate to manipulate nitrogen metabolism in the rumen of sheep fed on a silage-based diet. Proceedings of the 8th Silage Conference, Hurley 1987, pp. 69-70. Hurley: Institute for Grassland and Animal Production.

Ørskov, E. R. \& McDonald, I. (1979). The estimation of protein degradability in the rumen from incubation measurements weighted according to rate of passage. Journal of Agricultural Science, Cambridge 92 , 499-503.

Peyraud, J. L. (1987). Comparaison de l'oxyde de chrome et de l'ytterbium pour la mésure des flux duodénaux par simple et par double marquage chez la vache laitière. (Comparison of chromic oxide and ytterbium as single or dual markers for the measurement of duodenal flow in lactating cows.) Reproduction, Nutrition, Développement 27, 223-224.

Rooke, J. A., Alvarez, P. \& Armstrong, D. G. (1986). The digestion by cattle of barley and silage diets containing increasing quantities of soya-bean meal. Journal of Agricultural Science, Cambridge 107, 263-272.

Rooke, J. A. \& Armstrong, D. G. (1987a). The effect of different forms of N upon N digestion in the rumen of cattle receiving grass silage diets and intra-ruminal infusions of sucrose. Proceedings of the 8th Silage Conference, Hurley 1987, pp. 71-72. Hurley: Institute for Grassland and Animal Production.

Rooke, J. A. \& Armstrong, D. G. (1987 b). The digestion by cattle of silage and barley diets containing increasing quantities of fishmeal. Journal of Agricultural Science, Cambridge 109, 261-272.

Rooke, J. A., Griefe, H. A. \& Armstrong, D. G. (1985). The digestion by heifers of silage-containing diets fed at two dry matter intakes. 1. Digestion of organic matter and nitrogen. British Journal of Nutrition 53, 691-708.

Rooke, J. A., Lee, N.-H. \& Armstrong, D. G. (1987). The effects of intraruminal infusions of urea, casein, glucose syrup and a mixture of casein and glucose syrup on nitrogen digestion in the rumen of cattle receiving grasssilage diets. British Journal of Nutrition 57, 89-98.

Rooke, J. A., Maya, F. M., Arnold, J. A. \& Armstrong, D. G. (1988). The chemical composition and nutritive value of grass silages prepared with no additive or with the application of additives containing either Lactobacillus plantarum or formic acid. Grass and Forage Science 43, 87-95.

Ross, G. J. S. (1980). Maximum Likelihood Program. Rothamsted: Rothamsted Experimental Station.

Siddons, R. E., Evans, R. T. \& Beever, D. E. (1979). The effect of formaldehyde treatment before ensiling on the digestion of wilted grass silage by sheep. British Journal of Nutrition 42, 535-545.

Siddons, R. E., Nolan, J. V., Beever, D. E. \& MacRae, J. C. (1985a). Nitrogen digestion and metabolism in sheep consuming diets containing contrasting forms and levels of N. British Journal of Nutrition 54, 175-187.

Siddons, R. C., Paradine, J., Beever, D. E. \& Cornell, P. R. (1985b). Ytterbium acetate as a particulate-phase digesta-flow marker. British Journal of Nutrition 54, 509-519.

Thomas, P. C., Chamberlain, D. G., Kelly, N. C. \& Wait, M. K. (1980). The nutritive value of silages. Digestion of nitrogenous constituents in sheep receiving diets of grass silage and grass silage and barley. British Journal of Nutrition 43, 469-480.

Thomson, D. J., Beever, D. E., Lonsdale, C. R., Haines, M. J., Cammell, S. B. \& Austin, A. R. (1981). The digestion by cattle of grass silage made with formic acid and formic acid-formaldehyde. British Journal of Nutrition 46, 193-208.

Van Soest, P. J. \& Wine, R. H. (1967). Use of detergents in the analysis of fibrous feeds. IV. Determination of plant cell-wall constituents. Journal of the Association of Official Analytical Chemists 50, 50-55. 